\title{
A Time-Lag Study on Perceived Threat of COVID-19 in Hindu Religious Community: Moderating Role of Hindu Religious Coping
}

\author{
I Nyoman Sueca ${ }^{1}$ \\ Universitas Hindu Negeri I Gusti Bagus Sugriwa, Denpasar, Indonesia \\ I Wayan Sumertha \\ Institut Agama Hindu Negeri Gde Pudja, Mataram, Indonesia \\ I Wayan Winaja \\ Universitas Hindu Indonesia, Denpasar, Indonesia
}

\begin{abstract}
The COVID-19 pandemic had a serious impact on developing various psychological stressors in society. Grounded in cognitive appraisal theory, the current study has been conducted to investigate the moderating role of Hindu religious coping in mitigating the impact of the perceived threat of COVID-19 in developing perceived stress, insomnia, anxiety, and depression among the Hindu residents in Bali, Indonesia. The current study contributed to the body of knowledge regarding religious practices acting as a coping mechanism to help the community cope with crises scenario such as COVID-19. Using a longitudinal field survey, data were collected at two different times from 423 Hinduism believers who actively practiced religion and lived in Bali, Indonesia. Data were analyzed using measurement and structural models in SmartPLS. Results revealed that the perceived threat of COVID-19 impacted a higher level of stress, insomnia, anxiety, and depression among the target sample. Results further depicted that the intensity of the perceived threat of COVID-19 to develop negative stressors among those individuals is low who believe in Hinduism and practice religious obligations on a regular basis. This reflects the moderating role of Hindu religious coping in decreasing stress, insomnia, anxiety, and depression among Hindu believers aimed at COVID-19.
\end{abstract}

Keywords: anxiety, coping, COVID-19, depression, Hindu religious, Insomnia.

The novel coronavirus was declared as a pandemic in March 2020 by WHO (World Health Organization). This set a sudden panic and posed threats and challenges across the globe due to accelerated transmission and huge life loss in Europe, China, the US, and various other countries (Conway III et al., 2020a). Furthermore, media and social media reporting the rising death toll, an increasing number of cases also added to the hype and negative influence on people's psychological wellbeing (Ramkissoon, 2020). Moreover, the virus caused distress due to personal loss, adverse health conditions, and scarcity of resources to control its spread (Barzilay et al., 2020). Furthermore, the strict lockdowns around the world caused the closure of public places and recreational centers and created isolation for loved ones and friends to enforce social distancing.

${ }^{1}$ Correspondent Author E-Mail: inyomansueca64@gmail.com 
Besides, poor economic conditions, job loss, and strain on health departments caused psychological distress in the masses (Limcaoco et al., 2020). Therefore, this study aims to make an incremental advance by proposing the impact of perceived COVID-19 threat on the various psychological stressors.

The most evident result of the COVID-19 is perceived stress related to its spread into people, communities, and countries (Greene \& Park, 2021; Liu et al., 2021a). As COVID-19 is not restricted to boundaries of religion, race, status, facilities, or geographical location, it can affect anyone at any time unless precautionary measures are taken (Rahiem \& Rahim, 2020). This leads to feelings of uncertainty and raises fear among people. Stress is related to feelings and thoughts that an individual perceives regarding an object, situation, or challenge (Sikhangezile \& Modise, 2020). It creates feelings of uncontrollability and unpredictability among individuals (Sawatsuk et al., 2018). Stress challenges one's ability to cope with the situation, both mentally and physically (Rodriguez et al., 2020). If not dealt with in time, stress can lead to long-term physical and mental illness. Therefore, this study explores the perceived stress concerning COVID-19.

Another side effect caused due to COVID-19 and what many people faced during the pandemic, including frontline health workers, is insomnia. It is a sleep disorder that makes trouble falling asleep or staying asleep for a person (Hertenstein et al., 2019). It can be short-term acute or can last longer. The most common cause of insomnia is an irregular sleep schedule and physical environment that can hinder peaceful sleep (Patel et al., 2018). It can also occur due to medical conditions, such as neurological disorders. As COVID-19 changed the way we lived and interacted with each other, sleep problems have risen dramatically (Voitsidis et al., 2020). The virus brings various challenges to day-to-day activities; the perceived threats and uncertainties associated with it make it difficult for various people to continue a normal and healthy routine (Aliyyah et al., 2020). Very few studies have focused on COVID-19 effects on insomnia (Voitsidis et al., 2020); therefore, current research expects to advance the field by exploring the COVID-19 impact on insomnia.

Besides, anxiety is related to excessive nervousness, fear, apprehension, and worry (Bandelow et al., 2017). It is the body's natural response to stress and formulates the apprehension of fear and uncertainty (Ahmadi, 2021). The major cause of anxiety due to the virus is its property of being a-symptomatic in various people, which means that a person might be a carrier of the virus and be unaware of it due to the absence of symptoms (Barzilay et al., 2020). Anxiety can also be for loved ones facing the virus, i.e., kids, friends, and close relations, for which a person fears health and safety (Moghanibashi-Mansourieh, 2020). It has been explored in the past among cancer patients (Ng et al., 2017) and medical students (Francis et al., 2019) due to various reasons. Whereas, in the current study, we will explore the anxiety among the Hinduism practicing community residing in Bali, Indonesia, caused due to the threat of COVID-19, which has not been studied before, together with stress, insomnia, and depression. Thus, current research is making an advance by bridging this gap on a unique sample.

Depression is a serious and common mental illness these days (Aqeel et al., 2020). It can cause alienation in people, and in worst cases, lead to suicide and drug abuse. Several predictors of depression have been studied in different contexts (Nedal \& Alcoriza, 2018). At the same time, the current study is conducted to study the perceived threat of COVID-19 as a predictor of depression among the Hindu community living in Bali, Indonesia. As millions of people lost their lives due to the virus, young and old, friends and family faced depression and hopelessness with continuing a healthy and happy life (Özdin \& Bayrak Özdin, 2020); therefore, it is important to study the impact of depression faced by individuals due to COVID-19 which has been explored in the current study. 
Adding to that, the most important factor explored in this study is Hindu religious coping, which is expected to help cope with mentioned negative psychological factors caused due to the pandemic. Positive religious coping has been reported to improve individuals' mental well-being (O'Brien et al., 2019; Van Tongeren et al., 2018). The impact of prayers, visiting mosques/temples/churches, spiritual exercise, and other religious activities promote a sense of wellness and calmness among followers (McElroy-Heltzel et al., 2018). Besides, Hindu religious coping helps overcome the fear, anxiety, and uncertainty associated with the virus by instilling faith and hope in better days (Foroutani, 2020). Besides, there is a scarcity of research on positive aspects and phenomena that help people sustain challenging environmental conditions such as COVID-19. Therefore, responding to the research gap, this study made an advance by investigating the moderating effect of Hindu religious coping of the Hindu religious community in Indonesia to combat psychological stressors arising due to the perceived threat of COVID-19.

Moreover, this study is focused on the Hindu religious community in Indonesia and how they respond to psychological stressors. Hindus form a minority in Indonesia and mostly resided in Bali and nearby islands in Indonesia (Wu \& Ida, 2018). Hinduism strongly believes in spiritual well-being through mediation and yoga, like Dhyana, Pranayama, and Moksha practices (Megatsari et al., 2020). These techniques help bring calmness and emotional stability in individuals to combat uncertain and disastrous situations (Sulistyawati et al., 2021). Moreover, Indonesia's Hindu community in Indonesia has formulated a "Loka Sambharghara"(Joyo, 2020), which provides resource awareness to community members to deal with the virus. The selection of context for this research has some strong reasons, such as Bali is a Hindu majority area in a populated Muslim country. Also, a low death rate due to COVID-19 has been reported in Bali compared to other regions of Indonesia, which shows that Bali residents could successfully manage the threat of COVID-19 compared to other parts of Indonesia (Katipana et al., 2021). Thus, providing a point of investigation to identify those factors helped Bali residents cope with pressures to sustain in COVID-19 times (Feng et al., 2020). As the majority is Hindu population in Bali, this research pitched a thesis that religious factors such as Hindu religious coping are the constructs that may have played a positive role in helping the Hindu practicing community better sustain in these challenging times.

Furthermore, the current study is grounded in cognitive appraisal theory, which deals with individuals' psychological stress and coping mechanisms (Choi \& Choi, 2019). It is associated with a personal interpretation of the situation that influences the perception of being stressed (Choi \& Choi, 2019). Thus, the theory and contextual match provide significant room for this research to advance the literature in COVID-19, psychological stressors, and religious studies domains. Therefore, the current study aims to answer the following question.

- Is the perceived threat of COVID-19 positively associated with perceived stress, insomnia, anxiety, and depression among the Hindu community residing in Bali, Indonesia?

- Do Hindu religious coping moderates the association of perceived threat of COVID-19 with perceived stress, insomnia, anxiety, and depression among the Hindu community residing in Bali, Indonesia? 


\section{Theoretical Foundation and Literature Review}

\section{Theoretical Foundation}

Cognitive Appraisal Theory refers to a person's perception of a stress-related situation affecting his wellbeing and how that person interprets that situation outcome called appraisal, to act in a certain way (Broekens et al., 2008). Every individual has varied resources to cope with a stressful situation. The appraisal deals with evaluating any situation through a cognitive process over the risks involved in coping (Choi \& Choi, 2019). Besides, every emotion is generated based on a certain cognitive process in response to an uncertain situation, and different coping mechanisms vary with individuals' abilities, perception of threats, and resources available to cope with these situations (So et al., 2016). Whereas COVID-19 has caused prolonged stress over time in individuals, governments, and policymakers, affecting their quality of life, mental wellbeing, and mortality rate (Paredes et al., 2021). Millions of people worldwide have been affected by the spread of the virus, and various have gone through chronic stress and mental illness (Conway III et al., 2020b). In connection to that German finance minister committed suicide on March 29, 2020, due to the overpowering stress of coping with economic fallout due to covid19. Therefore, some coping mechanisms are required to deal with the psychological stressors arising from the perceived threat of COVID-19 (Namli, 2021; Rodriguez et al., 2020). Hence, rooted in cognitive appraisal theory, this study is set to evaluate the interactive effect of Hindu religious coping with the perceived threat of COVID-19 to decrease the level of perceived stress, anxiety, insomnia, and depression among the Hinduism practicing population in Bali, Indonesia.

\section{Relationship of Perceived Threat of COVID-19 with Perceived Stress, Insomnia, Anxiety, and Depression}

The perceived threat related to the spread of COVID-19 eventually leads to life loss worldwide (Garbe et al., 2020). As the death toll due to the virus rises globally in millions, reporting thousands of deaths every day, the perceived stress increases among the masses. Recent research shows that risk communication should be designed keeping in mind the psychological impact it will have on people's mental health (Liu et al., 2021b). Moreover, literature has linked negative health outcomes to the suspects of being feared with the virus (Rodriguez et al., 2020). Simultaneously, the perceived threat of COVID-19 has been associated negatively with an individual's subjective wellbeing (Paredes et al., 2021b). Besides, perceived stress is linked to low satisfaction, self-efficacy, and motivation (Shah et al., 2010). It has also been related to people's perception of stressfulness in their lives (Radcliffe \& Lester, 2003). Research indicates that the more a person fears the negative outcome, the higher will be the stress level (Lee, 2012; Rahiem $\&$ Rahim, 2020). Therefore, according to the cognitive appraisal theory, which advocates that a person's perception of a stress-related situation depicts his/her emotions and behaviors accordingly based on the interpretation of the situation (Tsurumi et al., 2020); it is projected that the perceived threat of COVID-19 will increase the level of perceived stress and among individuals.

H1: The perceived threat of COVID-19 is positively associated with perceived stress. 
The perceived threat is related to perceived risks associated with a situation (Irshad et al., 2020). Research shows that there is a sufficient increase in sleep medication prescriptions across the US during the pandemic to deal with the patients (Voitsidis et al., 2020). A good peaceful sleep, i.e., 7 to 8 hours in grownup, is necessary to maintain healthy body functions, as during sleep body release growth hormones, which help the body grow and repair (Patel et al., 2018). Besides, insomnia relates to sleep deprivation or the inability to maintain continued sleep due to stress (Yamamori, 2019). On the other hand, the perceived threat has been associated with causing alertness in animals and humans; as the mind perceives danger and risk from a person or situation, it releases epinephrine to deal with the situation (Kim, 2020). This can affect a person's ability to sleep effectively, as the mind continuously evaluates the situation and appraises the outcomes (Hertenstein et al., 2019). Although there are not enough pieces of evidence available in the literature investigating the impact of the perceived threat of COVID-19 on insomnia, however, a study conducted by Rodriguez et al. (2020) suggests that the perceived threat of COVID-19 can cause uncertainty and distress, affecting a person's physical and mental health. Therefore, to bridge this gap in the literature and based on the cognitive appraisal theory, which suggests that every emotion and behavior results from a certain cognitive process in response to an uncertain situation. This study argues that due to stress and perceived threat of COVID-19 a direct relationship is expected between perceived threat of COVID-19 and insomnia.

\section{H2: The Perceived COVID-19 threat is positively associated with insomnia.}

The perceived threat of COVID-19 has caused panic worldwide (Megatsari et al., 2020). Countries have been found to close their borders, enforce travel bans, close public places, and abandon all social activities in response to the perceived threat of COVID-19 and its accelerated effects widespread (Kalyani, 2020). COVID-19 posts major health risk for the elderly, as the global death rate of persons above 55 is reported to be $75 \%$ compared to younger people due to underlying medical conditions, immunity to fight with the virus, and psychological stressors (Barzilay et al., 2020). This is causing major anxiety levels in individuals, especially those who fear their loved ones' health. Anxiety refers to a person's perceived uncertainty related to feelings of worry, tension, and physical response of the body like accelerated heart rate and blood pressure (Bandelow et al., 2017). Besides, anxiety can be caused due to the death of a loved one, work stress, a changing situation, encountering a new environment, etc. Anxiety has also been linked to personality traits, such as anger, frustration, self-esteem, and desire to control everything (Liu et al., 2021b). Moreover, Chapman and Steger (2010) depicted that timid, shy, or inhibited people try to avoid risks or challenging situations due to a higher anxiety level. On the other hand, there is a scarcity of literature related to the link of the perceived threat of COVID-19 with the anxiety of the individuals. Therefore, to bridge this gap in the literature and based on the prolonged effect of the pandemic in affecting quality of peoples' life, mental wellbeing, and mortality rate it is predicted that perceived threat of COVID-19 has a direct impact on anxiety among individuals.

\section{H3: Perceived COVID-19 threat is positively associated with anxiety.}

Perceived COVID-19 threat poses risks for losing contact with loved ones due to the government's strict lockdowns (Aqeel et al., 2020). It can cause feelings of hopelessness and disappointment among many, as they face financial, psychological, and emotional strain amid the perceived threat of covid19 (Counted et al., 2020). Although human beings have been blessed with 
a biological system to deal with loss, the grieving process is natural and unique to every individual. However, the inability to overcome the personal loss of a loved one or a major setback in one's career can lead to feelings of depression (LeMoult \& Gotlib, 2019). Besides, depression deals with withdrawal from regular activities associated with negative behaviors like mood swings, alienation, memory loss, and weakening of the immune system (Putnam et al., 2017). It is characterized by ongoing changes in physical, psychological, and social dimensions (Özdin \& Bayrak Özdin, 2020). Youth have been reported to go through depression during the current pandemic due to closure of educational institutions (Dalle \& Ariffin, 2018), social distancing with friends, loneliness due to quarantine, and loss of physical activities due to a ban on outdoor areas and sports (Özdin \& Bayrak Özdin, 2020). Thus, the current study argues a direct link between the perceived threat of Covid 19 in creating depression among the Hindu community living in a Muslim majority country Indonesia.

H4: The perceived threat of COVID-19 is positively associated with depression.

\section{The Moderating Role of Hindu Religious Coping between the Perceived Threat of COVID-19 with Perceived Stress, Insomnia, Anxiety, and Depression}

Religion can greatly impact how one deals with negativity in life, especially stress (Wasike, 2017). Previous studies indicate that religion improves emotional and psychological wellbeing through instilling faith and positive thinking in followers (Ahles et al., 2016). Furthermore, various studies indicate that positive religious coping decreases stress among their followers; through being spiritually focused, negative emotions are reduced (Ahles et al., 2016; Luczak \& Kalbag, 2018). In addition, it creates a sense of connectedness in the community and feelings of self-compassion, self-esteem, and mindfulness for individuals (O'Brien et al., 2019). Moreover, Hindu religious coping has been linked to benevolent religious appraisals and optimism (Abu-Raiya et al., 2020); therefore, it can reduce the impacts of the perceived threat of COVID-19 by continuously seeking protection through prayers.

Besides, during pandemic times, different religions, i.e., Hinduism, Christianity, Buddhism, Islam, etc., have been reported to be a source of mental well-being and peace of mind of the believers (Thomas \& Barbato, 2020). Adding to that, the Hindu community utilizes the vision of good in the world through their belief in the Gods, who cure the ill and mend the heart of the unwell (Joyo, 2020). Therefore, it can be well said the those who believe in Hinduism take less stress of the unusual situations as they associate positive outcomes of any situation via Hindu religious coping. Despite several studies related to the role of positive religious coping in decreasing stress among believers, none of the studies have investigated the interactive effect of Hindu religious coping with the perceived threat of COVID-19 to decrease the level of stress among individuals.

H5: Hindu religious coping moderates the association between the perceived threat of COVID-19 and perceived stress among the Hindu community such that the higher values of Hindu religious coping will result in less perceived stress among the Hinduism practicing individuals. 
Religious coping increases one's satisfaction with life by exerting efforts to please God through the exhibition of spirituality (Heo, 2014), based on the fact that various religious acts include healing of body and soul, improving the psychological and mental wellbeing of a person (Mohammadzadeh \& Najafi, 2020). Religion provides a person with a sense of purpose in conducting one's life and relating to others (Van Tongeren et al., 2018). Religion can help reduce feelings of fear and uncertainty, as most religions promise rewards in the afterlife and health and safety due to following religious values (Park et al., 2018). Perceived threats and risks can be reduced by strongly believing that following religious guidelines can protect against mental and physical harm. Inner peace and harmony accounted through spirituality can improve one's sleep and reduce insomnia (Pillai et al., 2014). Hence, cognitive appraisal theory can guide the path that exhibiting Hindu religious coping can help overcome fears and threats related to COVID-19 and improve sleep through mental peace. In this way this research argues that when Hindu religious coping will interact with an individuals' fear associated with the perceived threat COVID-19, the coupled effect is expected to decrease the level of insomnia in that individual.

H6: Hindu religious coping moderates the association between the perceived threat of COVID-19 and perceived insomnia in the Hindu community such that the higher values of Hindu religious coping will result in less insomnia among the Hinduism practicing individuals.

Religious coping relates to seeking religious guidance in difficult times through prayers, submission, and God's providence (Bay et al., 2008). This leads to the appraisal of obstacles considering religious teaching on acting when faced with a threat to one's wellbeing (Chapman \& Steger, 2010). Therefore, the perceived threat of COVID-19 can be overcome by asking for resort, protection, and safety from God and spiritual forces to help combat the virus for oneself and loved ones (Mohammadzadeh \& Najafi, 2020). Furthermore, many religious countries and governments have asked religious leaders to provide guidance and instill hopes in times of uncertainty; as human resources and abilities are challenged by the current virus, they seek help from God (Counted et al., 2020). Besides, anxiety relates to the unpredictability of a situation concerning the risks involved (Fetzer et al., 2020).

On the other hand, religion ensures rewards for those following religious guidelines and punishments for others that fail to comply (Francis et al., 2019). Therefore, religion can help reduce anxiety by predicting positive and negative outcomes of one's actions. Religion provides assurance, stability, and perseverance in one's life. Research shows that people who follow religion feels less anxious compared to those that do not practice religion in their life ( $\mathrm{Ng}$ et al., 2017). Moreover, in a study conducted among India's Hinduism community, Ahmad, Rahman, and Agarwal (2020) reported a low level of anxiety among the strong believers in religion. Thus, based on the literature support and cognitive appraisal theory, which posits that different individual use different resources to cope with a stressful situation; we believe that in this study case religious practices act as coping mechanism while combined with perceived threat of COVID-19 to decrease its impact on anxiety among the Hinduism practicing believers.

H7: Hindu religious coping moderates the association between the perceived threat of COVID-19 and anxiety among the Hindu community such that the higher values of Hindu religious coping will result in less anxiety among the Hinduism practicing individuals. 
Religious coping gives courage and the ability to cope with the perceived threat by taking necessary actions. The link between depression and religiosity raises the question of the possible mechanisms through which religion might play this protective role (Bosworth et al., 2003). Research indicates that religion infuses a sense of purposefulness and dutifulness towards God and humanity (Van Tongeren et al., 2018). This can eradicate the feelings of disappointment with one's life by focusing on achieving religious compatibility to succeed in this life and hereafter (Thomas $\&$ Barbato, 2020). Besides, Hindus strongly believe in several lives after death, and one earning the fruit of his/her actions through gaining a positive or negative role in coming lives (Joyo, 2020). Therefore, the Hindu community strongly believes in exhibiting strong religious virtues to earn a better afterlife through a positive outlook and religious coping, especially dealing with depression (Putnam et al., 2017). Thus, keeping in view the cognitive appraisal theory that incorporates religious coping can ensure overcoming the negative feeling of injustice and dissatisfaction with one's life; it can be said that Hindu religious coping results in the possibility of decreasing depression and mitigates the effect of the perceived threat of COVID-19 among individuals.

H8: Hindu religious coping moderates the association between the perceived threat of COVID-19 and depression among the Hindu community such that the higher values of Hindu religious coping will result in less depression among the Hinduism practicing individuals.

\section{Theoretical Framework of the Study}

\section{Figure 1}

Theoretical Framework of the Study

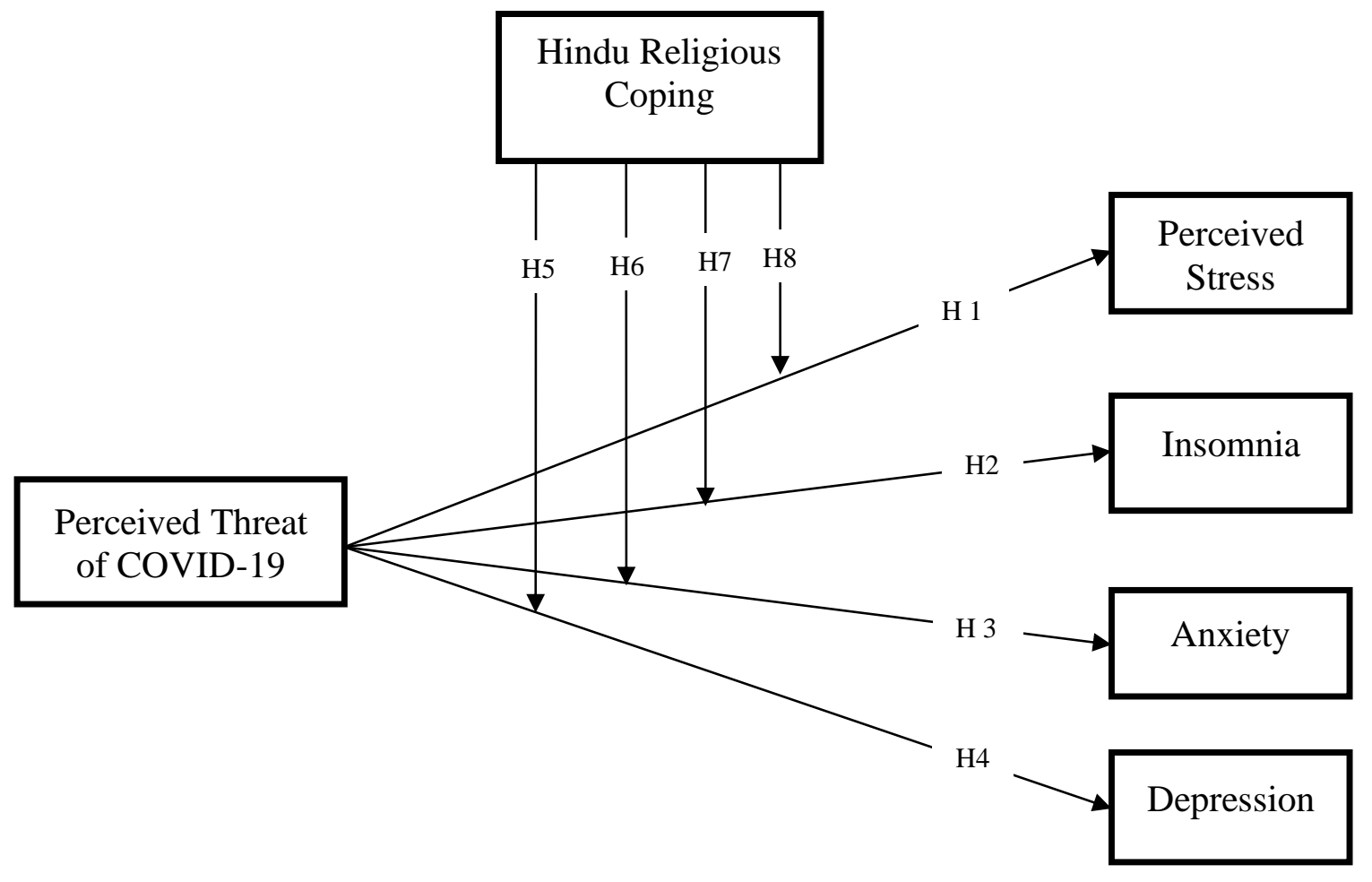




\section{Research Methods}

\section{Participants and Context of the Study}

The study's main objective was to determine the moderating role of Hindu religious coping in the association of the perceived threat of COVID-19 with psychological stressors like perceived stress, insomnia, anxiety, and depression among the Hindu community living in Bali, Indonesia. This research adopted a quantitative longitudinal field survey methodology by disseminating 47 items questionnaire among the Hinduism practicing community in Bali, Indonesia. This research design is in line with the methods applied by (Szabo et al., 2017). Data was collected from the Hindu community, visiting the Hindu Temples in Bali, Indonesia. Moreover, the respondents' demographic characteristics depict that $68.8 \%$ of respondents were male, and $31.2 \%$ were females. $49.4 \%$ were from the age bracket of $20-30$ years, $36.4 \%$ were in the age bracket of $31-40$ years, and $14.2 \%$ of respondents were above 50 years of age. $54.3 \%$ of the respondents were graduates, $24.3 \%$ were undergraduate, and $21.4 \%$ were postgraduates and highly qualified. $59.5 \%$ of respondents were married, whereas $41.5 \%$ were unmarried. Participants' age ranged from 20 to 68 years, with a mean of 38.33 years $(S D=6.29) .38 .7 \%$ of respondents were employed, $29.2 \%$ were self-employed, $12.6 \%$ were retired individuals, $11.9 \%$ were unemployed, and $07.6 \%$ were housewives. The majority of the respondents $(89.5 \%)$ depicted that they practice religious obligations daily, indicating that the selected sample for the current study was highly representative of the study's targeted religious concept.

\section{Data Collection Procedure}

In the first stage, authors visited several Hindu temples in Bali and met with their administrators to discuss the study objectives and seek their willingness to support this initiative. During discussions, the social class and status of most followers were explored from the information obtained by temple administrators. Most administrators were happy to support because they believe this study will help promote their religious practices' effectiveness. However, the authors only selected the ten most populated temples where the most educated class people were regular temple visitors and had specific regular connections and communication with administrators to support the temple and its activities. After shortlisting, each temple administrator requested contact information of at least 150 followers and believers who regularly visit and support temple activities. By this, the authors had a list of social media contacts of 1500 followers and believers of Hinduism visiting ten selected temples in Bali, Indonesia.

In the second stage, all believers were contacted by study authors through social media and explained that the study objectives and anonymity were also ensured to seek their voluntary willingness to participate in a time-lagged study. Almost 110 social media contacts were not operational or closed or not responding with initial screening, so those were dropped. Those who responded, around 230 contacts, refused to participate in the study. Thus, the authors left with 1160 contacts who agreed to participate. These 1160 individuals were asked for their English proficiency to read and understand the English language survey. With this scrutiny, 260 people were excluded from the survey due to their low English level. As all the survey scales were adapted from literature with good, reported reliability, the same adopted English version was used to avoid translation and back translation issues (Noor et al., 2021; Putra et al., 2021). Also, as in Indonesia, English is a commonly understood language in educational institutions, and most of our data respondents had 
a qualification under-graduate and above, which depicts that the respondents were able to understand the survey language fully (Kasim et al., 2020).

The authors left with 900 agreed individuals with good English proficiency levels. As religion is a sensitive matter, respondents were ensured that this study is not being conducted to create any religious prejudice or bias in the country or the community, and their responses will never be shared with any third party at any stage of the study. Thus, in the third stage, the google survey questionnaire was sent to all 900 participants using their social media contacts at time 1 in the first week of August 2020. The respondents were asked to provide information about demographics, and items related to the perceived threat of COVID-19 and Hindu religious coping were taped. This phase was completed in one month by continuous follow-ups and reminders, so the author received 680 filled responses. Upon scrutiny, it was realized that some of the responses were partially filled or unengaged, so such responses were excluded, and the authors had a final response of 652 questionnaires at time 1.

In the fourth stage, the same 652 respondents were contacted and requested to fill the survey at time 2 in the first week of January 2021. Again, the same procedure of reminders and followups was practiced earlier to finish the survey till the last week of January 2021. This time the respondents were asked to answer self-reported items related to perceived stress, insomnia, anxiety, and depression. In time two authors received 461 questionnaires back; after a detailed and careful screening, 38 incomplete and unengaged responses were excluded from further analysis. Finally, the remaining 423 questionnaires were left, which had complete pairs of responses for times 1 and 2. These 423 responses were included in the current study for analysis, generating a final response rate of $64.87 \%$.

\section{Measures of Study}

Existing measures with good reported reliabilities were adapted for the current study. The measure for the perceived threat of COVID-19, a four-item scale adapted from Tyler and Cook (1984) by specifying the COVID-19 pandemic as the threat concept mentioned, was used. The same scale has also been used by a recent study by Paredes et al. (2021a). Hindu religious coping was measured by 23-items from Tarakeshwar et al. (2003). Perceived stress (PSS-10) was used to assess the perceived stress among Hindu residents in Bali, Indonesia. It is a 10-items scale developed by Cohen et al. (1983). Insomnia Severity Index (ISI 7 item) was used to assess Insomnia. It is a seven-item scale adopted from Morin et al. (2011). Moreover, Generalized Anxiety Disorder-7 (GAD-7) has been used to assess the Hindu residents' anxiety in Bali, Indonesia. It is a seven-item scale developed by (Spitzer et al., 2006). Finally, to assess depression, "depression (PHQ-9)" adapted from (Kroenke et al., 2001) has been used in the current study.

\section{Data Analysis and Results}

SmartPLS was utilized in the current study to perform structural equation modeling (SEM) analysis. The results showed that none of the demographic constructs has a significant influence on dependent variables. Therefore, no demographic variable was taken as the control variable in the study. Moreover, applying the measurement model, CFA was performed utilizing SmartPLS3. Besides, "Cronbach's $\alpha$ " and "composite reliability (CR)" were calculated to assess the reliability of measures as per directions provided by Henseler et al. (2009a) and applied by many scholars like (Mansoor, 2021). Moreover, a detailed summary of reliability measures is given in Table 1 , showing a good model fit based on factor loadings ( $\Rightarrow 0.70)$, "Cronbach's $\alpha ">0.70$, and CR 
$>0.80$. In addition, the "Average Variance Extracted" AVE of latent variables was above 0.50 for all study constructs; therefore, "convergent validity "was established (Hair et al., 2010; Mansoor et al., 2020).

Table 1

Factor loadings, reliability, and validity

\begin{tabular}{|c|c|c|c|c|c|c|c|c|c|}
\hline Constructs/Items & 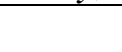 & & Factor I & ding & & & AVE & CR & Cronbach's $\alpha$ \\
\hline & 1 & 2 & 3 & 4 & 5 & 6 & & & \\
\hline $\begin{array}{l}\text { Perceived threat of } \\
\text { COVID-19 }\end{array}$ & & & & & & & 0.601 & 0.858 & 0.777 \\
\hline PTC1 & 0.803 & & & & & & & & \\
\hline PTC2 & 0.795 & & & & & & & & \\
\hline PTC3 & 0.791 & & & & & & & & \\
\hline PTC4 & 0.709 & & & & & & & & \\
\hline $\begin{array}{l}\text { Hindu religious } \\
\text { coping }\end{array}$ & & & & & & & 0.553 & 0.788 & 0.819 \\
\hline $\mathrm{HRC1}$ & & 0.713 & & & & & & & \\
\hline $\mathrm{HRC} 2$ & & 0.711 & & & & & & & \\
\hline HRC3 & & 0.794 & & & & & & & \\
\hline HRC4 & & 0.842 & & & & & & & \\
\hline HRC5 & & 0.730 & & & & & & & \\
\hline HRC6 & & 0.756 & & & & & & & \\
\hline HRC7 & & 0.753 & & & & & & & \\
\hline HRC8 & & 0.718 & & & & & & & \\
\hline HRC9 & & 0.816 & & & & & & & \\
\hline HRC10 & & 0.834 & & & & & & & \\
\hline HRC11 & & 0.723 & & & & & & & \\
\hline HRC12 & & 0.718 & & & & & & & \\
\hline $\mathrm{HRC} 13$ & & 0.735 & & & & & & & \\
\hline HRC14 & & 0.659 & & & & & & & \\
\hline HRC15 & & 0.733 & & & & & & & \\
\hline HRC16 & & 0.726 & & & & & & & \\
\hline HRC17 & & 0.751 & & & & & & & \\
\hline HRC18 & & 0.712 & & & & & & & \\
\hline HRC19 & & 0.750 & & & & & & & \\
\hline $\mathrm{HRC} 20$ & & 0.734 & & & & & & & \\
\hline HRC21 & & 0.702 & & & & & & & \\
\hline HRC22 & & 0.771 & & & & & & & \\
\hline $\mathrm{HRC} 23$ & & 0.697 & & & & & & & \\
\hline Perceived Stress & & & & & & & 0.558 & 0.926 & 0.827 \\
\hline PS1 & & & 0.748 & & & & & & \\
\hline PS2 & & & 0.771 & & & & & & \\
\hline PS3 & & & 0.779 & & & & & & \\
\hline PS4 & & & 0.730 & & & & & & \\
\hline PS5 & & & 0.703 & & & & & & \\
\hline
\end{tabular}




\begin{tabular}{|c|c|c|c|c|c|c|}
\hline PS6 & 0.784 & & & & & \\
\hline PS7 & 0.710 & & & & & \\
\hline PS8 & 0.639 & & & & & \\
\hline PS9 & 0.716 & & & & & \\
\hline PS10 & 0.702 & & & & & \\
\hline Insomnia & & & & 0.577 & 0.904 & 0.801 \\
\hline INS1 & 0.718 & & & & & \\
\hline INS2 & 0.710 & & & & & \\
\hline INS3 & 0.714 & & & & & \\
\hline INS4 & 0.781 & & & & & \\
\hline INS5 & 0.710 & & & & & \\
\hline INS6 & 0.778 & & & & & \\
\hline INS7 & 0.887 & & & & & \\
\hline Anxiety & & & & 0.524 & 0.885 & 0.782 \\
\hline ANX1 & & 0.694 & & & & \\
\hline ANX2 & & 0.767 & & & & \\
\hline ANX3 & & 0.717 & & & & \\
\hline ANX4 & & 0.740 & & & & \\
\hline ANX5 & & 0.703 & & & & \\
\hline ANX6 & & 0.717 & & & & \\
\hline ANX7 & & 0.727 & & & & \\
\hline Depression & & & & 0.538 & 0.903 & 0.812 \\
\hline DEP1 & & & 0.733 & & & \\
\hline DEP2 & & & 0.736 & & & \\
\hline DEP3 & & & 0.760 & & & \\
\hline DEP4 & & & 0.698 & & & \\
\hline DEP5 & & & 0.686 & & & \\
\hline DEP6 & & & 0.682 & & & \\
\hline DEP7 & & & 0.780 & & & \\
\hline DEP8 & & & 0.791 & & & \\
\hline DEP9 & & & 0.790 & & & \\
\hline
\end{tabular}

Note: CR, composite reliability; AVE, average variance extracted.

Table 2

Heterotrait-Monotrait Ratio

\begin{tabular}{lcccccccc}
\hline Constructs & Mean & STD. & 1 & 2 & 3 & 4 & 5 & 6 \\
\hline Perceived Threat of & 3.97 & 0.69 & 0.775 & & & & & \\
COVID-19 & & & & & & & & \\
Hindu Religious Coping & 4.01 & 0.61 & 0.511 & 0.743 & & & & \\
Perceived Stress & 3,88 & 0.73 & 0.479 & 0.423 & 0.746 & & & \\
Insomnia & 3.79 & 0.80 & 0.502 & 0.471 & 0.503 & 0.759 & & \\
Anxiety & 3.91 & 0.77 & 0.377 & 0.396 & 0.370 & 0.444 & 0.723 & \\
Depression & 4.12 & 0.56 & 0.391 & 0.385 & 0.359 & 0.407 & 0.328 & 0.733 \\
\hline
\end{tabular}

Note: The square roots of AVEs of the constructs are shown in bold in diagonal. 
While using SmartPLS3, the most appropriate measure of discriminate validity is Heterotrait-Monotrait (HTMT) ratio (Henseler et al., 2009b; Mansoor \& Noor, 2019; Noor et al., 2021). while using smart PLS, The HTMT ratio value should be less than 0.9 , as depicted in Table 2 that all values were less than 0.9 for the entire model.

\section{Figure 2}

\section{Full Measurement Model}

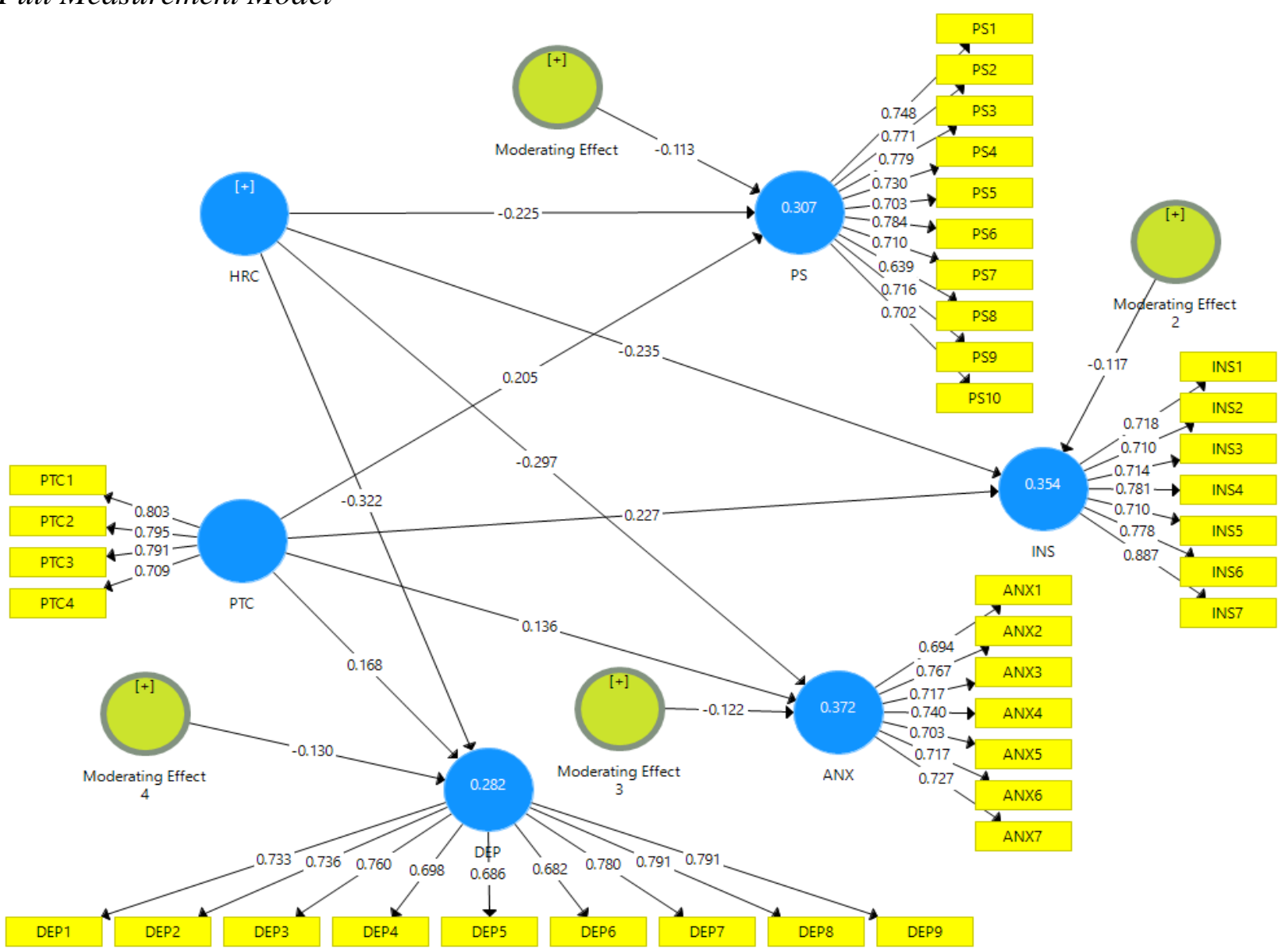

\section{Hypothesis Testing}

\section{Direct Hypothesis}

In Table 3 the results presented show a positive and significant relationship of perceived threat of COVID-19 with perceived stress $\left(B=0.205^{* * *}, \mathrm{t}=4.938\right)$, insomnia $\left(\beta=0.227^{* * *}, \mathrm{t}=\right.$ $5.606)$, anxiety $\left(\beta=0.136^{* *}, \mathrm{t}=3.337\right)$ and depression $\left(\beta=0.168^{* *}, \mathrm{t}=3.668\right)$. Therefore, $\mathrm{H} 1$, $\mathrm{H} 2, \mathrm{H} 3$ and $\mathrm{H} 4$ are fully supported by the study results. 


\section{Moderating Hypothesis}

To assess the moderating effect of a construct in PLS-SEM, interaction terms between the moderator, Hindu religious coping, and predictor perceived threat of COVID-19 was created using the product indicator approach to examine its effect on perceived stress, Insomnia, anxiety, and depression among the Hindu community individuals living in Bali Indonesia. The results show (Table 3) significant effect of interaction terms, Hindu religious coping*perceived threat of COVID-19 on perceived stress $(\beta=-0.113, t$-value $=2.606, p=.013)$, insomnia $(\beta=-0.117, t$-value $=2.735, p=.010)$, anxiety $(\beta=-0.122, t$-value $=3.109, p=.007)$ and depression $(\beta=-0.130, t$-value $=3.210, p=.006$ ). Moreover, along with the interactive effect, the $R^{2}$ change between the main effect model and the model with the interaction effect was also analyzed. The $R^{2}$ for the main effect of the perceived threat of COVID-19 on perceived stress was $\left(R^{2}=0.421\right)$, whereas its $R^{2}$ for the interaction effect of Hindu religious coping*perceived threat of COVID-19 increased to $\left(R^{2}=\right.$ $0.307)$. The $R^{2}$ change suggested that the moderating effect changed the explanatory power of the perceived threat of COVID-19 for perceived stress while decreasing it by $11.40 \%$; likewise, including an interaction term changed the explanatory of the perceived threat of COVID-19 by decreasing its impact on insomnia, anxiety, and depression of the Hindu community individuals in Bali Indonesia by $10.21 \%, 12.03$ and $14.17 \%$ respectively. Moreover, the negative association of moderator and dependent variable has been explained through the following moderation graphs.

\section{Figure 3}

Moderation of Hindu religious coping (HRC) in between the Perceived Threat of COVID-19 and Phycological distress

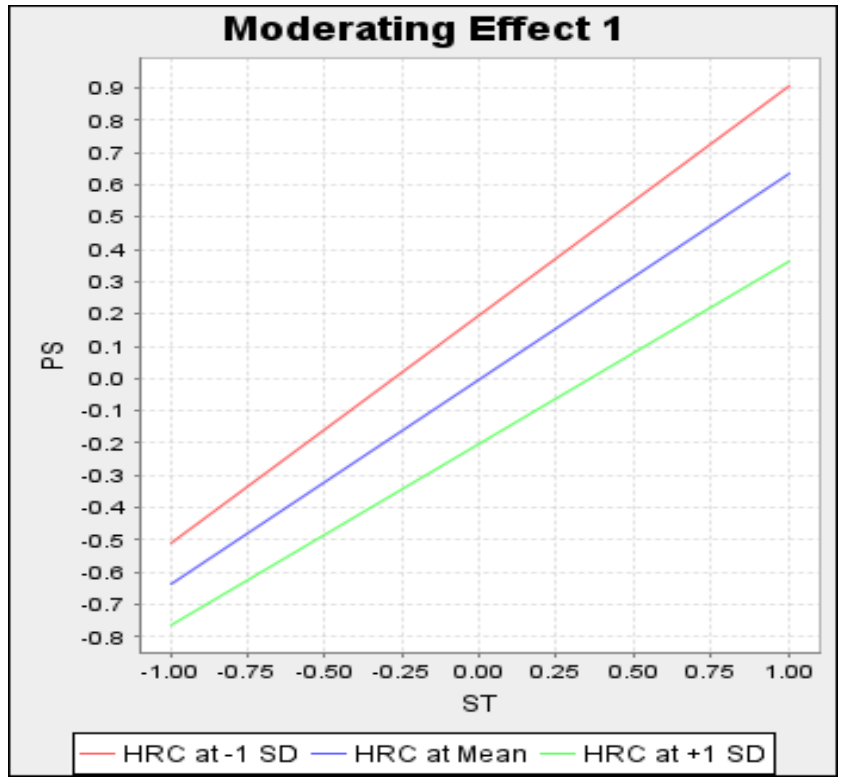

Figure 3 depicts a decrease in perceived stress among Hindu believers as the line labeled for a higher level of Hindu religious coping is less steep than the lower level of Hindu religious coping for the association of perceived threat of COVID-19 and perceived stress. This represents that the believers of Hinduism are more content and compact during pandemic times based on their religious teachings and practices. Thus, hypothesis 5 was supported. 


\section{Figure 4}

Moderation of Hindu religious coping (HRC) in between the Perceived Threat of COVID-19 and Insomnia

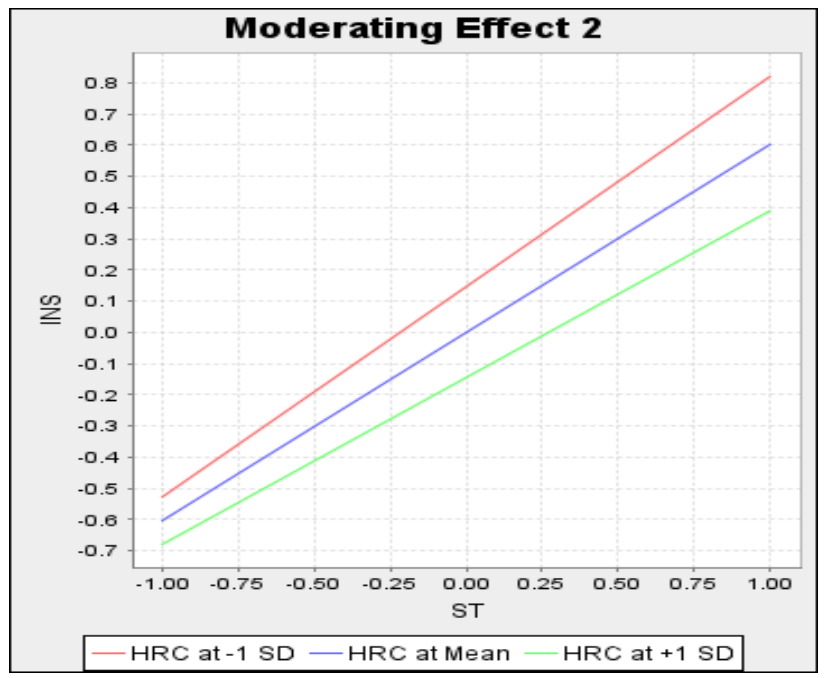

Figure 4 shows a decrease in intensity of the impact of the perceived threat of COVID-19 in building insomnia among the Hindu community individuals residing in Bali, Indonesia. Thus, reflecting the positive side of religious coping in making its believers calm and feel peace of mind to have a sound sleep without any tension and stress. Hence, hypothesis 6 was supported.

\section{Figure 5}

Moderation of Hindu religious coping (HRC) in between the Perceived Threat of COVID-19 and Anxiety

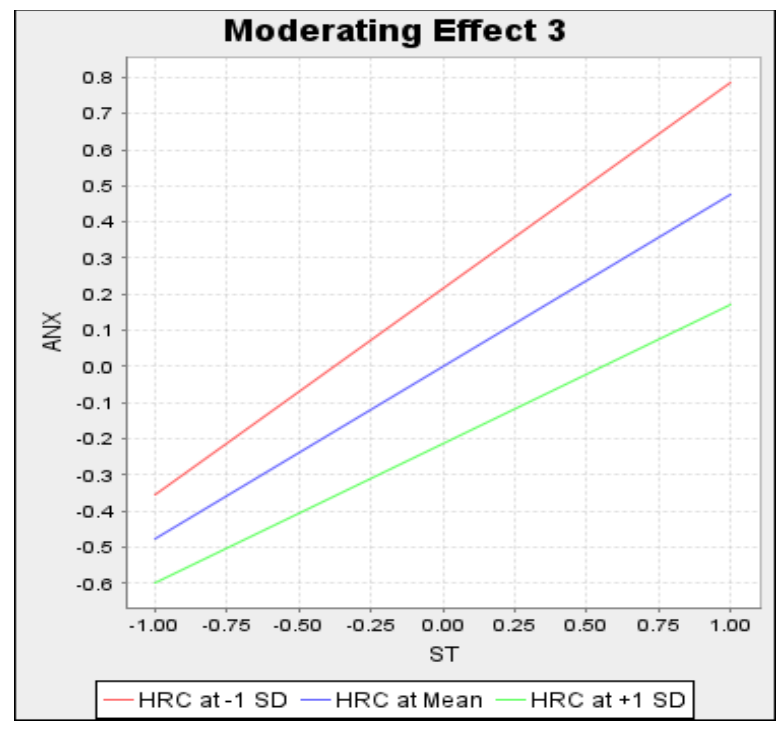

Moreover, as depicted in Figure 5, reflects that those Hindu residents of Bali are calm and relax with a low level of anxiety who believe in religious teachings that there come good and bad days and God is there to help them come out of the bad times. Hence, hypothesis 7 was supported. 
Figure 6

Moderation of Hindu religious coping (HRC) in between the Perceived Threat of COVID-19 and Depression

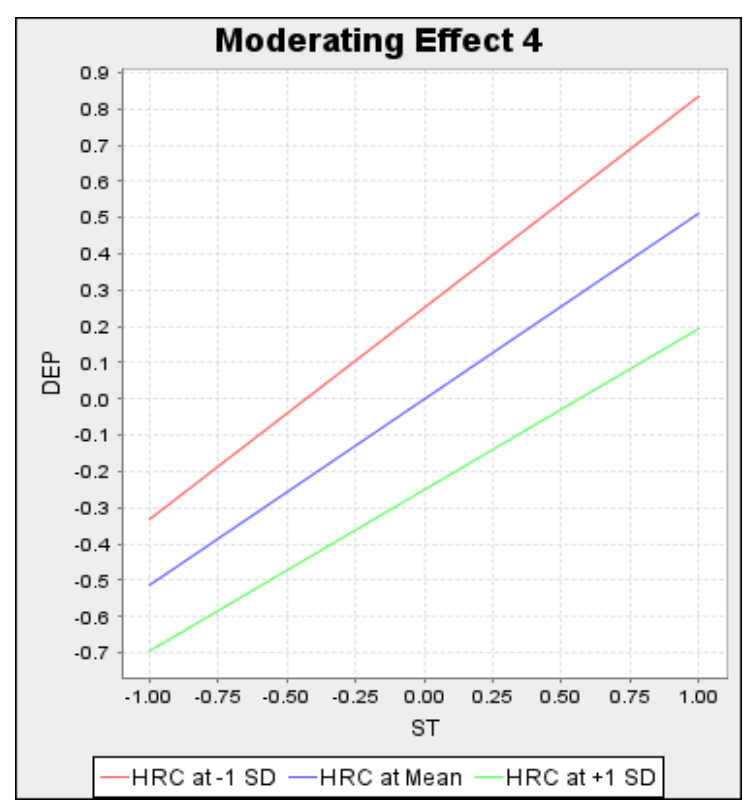

Likewise, as shown in Figure 6, represents that those Hindu individuals who practice their rituals more often are less fearful of being infected with COVID-19 as they believe in fate and destiny; therefore, they feel less depressed as they spend more time practicing their religion which makes them relax. Thus, hypothesis 8 was also supported.

Table 3

Hypothesis Testing Results

\begin{tabular}{llcccc}
\hline & Hypotheses & Std. Beta & t-Value & p-values & Findings \\
\hline H1 & PTC $\rightarrow$ PS & 0.205 & 4.938 & 0.000 & Supported \\
H2 & PTC $\rightarrow$ INS & 0.227 & 5.606 & 0.000 & Supported \\
H3 & PTC $\rightarrow$ ANX & 0.136 & 3.337 & 0.003 & Supported \\
H4 & PTC $\rightarrow$ DEP & 0.168 & 3.668 & 0.001 & Supported \\
H5 & PTC $*$ HRC $\rightarrow$ PS & -0.113 & 2.606 & 0.013 & Supported \\
H6 & PTC $*$ HRC $\rightarrow$ INS & -0.117 & 2.735 & 0.010 & Supported \\
H7 & PTC $*$ HRC $\rightarrow$ ANX & -0.122 & 3.109 & 0.007 & Supported \\
H8 & PTC $*$ HRC $\rightarrow$ DEP & -0.130 & 3.210 & 0.006 & Supported \\
\hline
\end{tabular}

Where: $P T C=$ Perceived Threat of COVID-19; HRC $=$ Hindu religious coping; $P S=$ Perceived Stress INS=Insomnia; $A N X=$ Anxiety; DEP=Depression. 


\section{Figure 6}

\section{Full Structural Model}

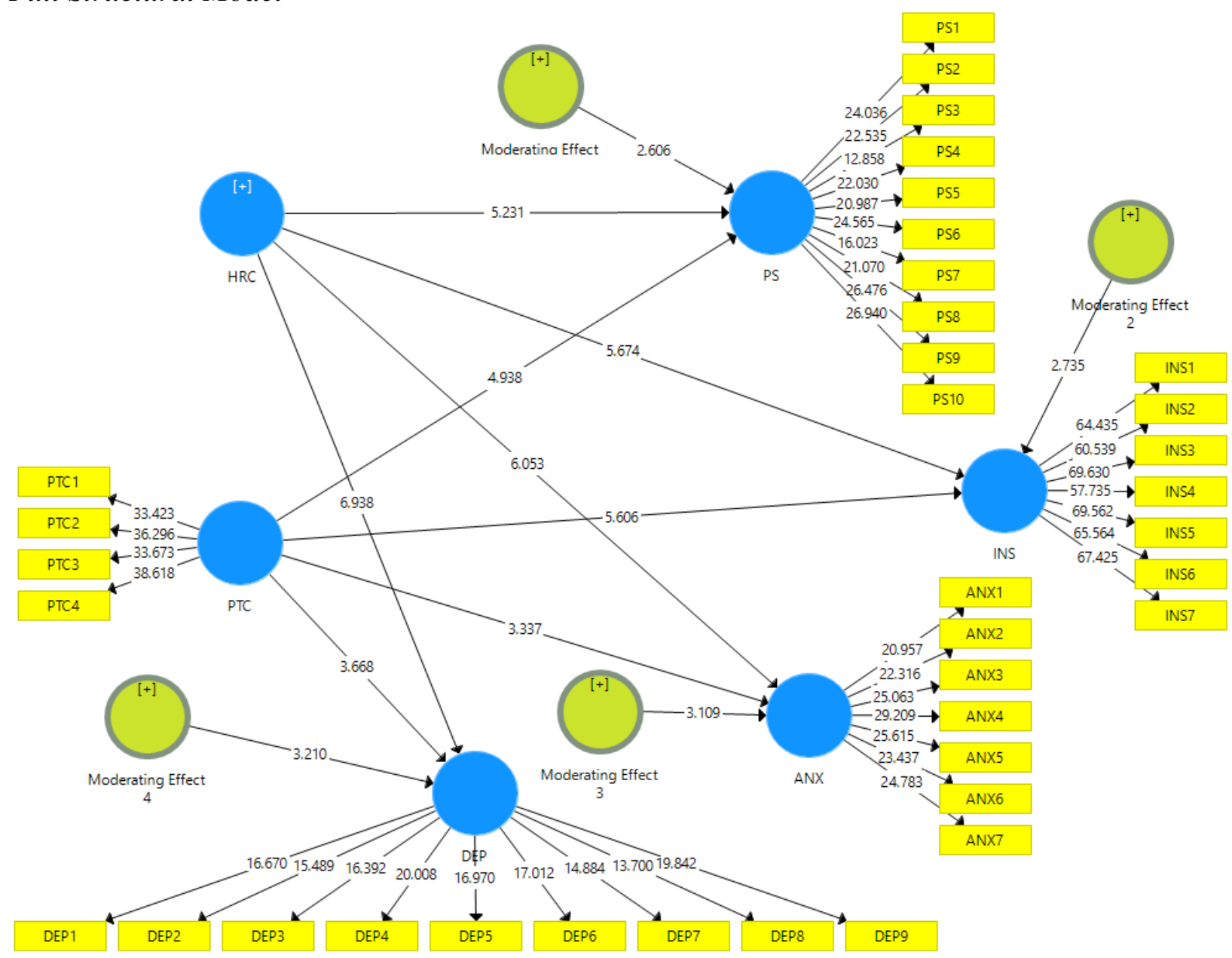

\section{Discussion, Implications, Limitations, and Future Directions}

\section{Findings of the Study}

The current study has been conducted among the Hinduism practicing individuals living in Bali, Indonesia; approximately $83 \%$ of Indonesian Hindus reside on Bali island (Singaram \& Saradaprabhananda, 2020). Simultaneously, during the pandemic Hindu community exhibited an important role in following SOP's and cooperating with the local authorities resulting in a less disastrous situation in Bali. Moreover, established on cognitive appraisal theory, an important role of Hindu religious coping has been explored to decreases the devastating effects of the perceived threat of COVID-19 among Hinduism believers. The findings of the current study revealed that the perceived threat of COVID-19 positively leads to perceived stress based on the understanding that the stress level in an individual develops due to the fears of a situation's negative outcome (Lee, 2012). Thus, when people believe that they and their loved ones are in danger due to a pandemic that is not curable and is universal, they automatically come under pressure, and there arises a fear of being a victim, which causes feelings of stress. 
Moreover, results also revealed a significant positive impact of the perceived threat of COVID-19 in causing insomnia. This is in line with the findings of Kim (2020), who depicted the direct association of the perceived threat with the preparedness of the mind to stay active and alert to deal with the projected danger, which can cause restlessness and shortage of sleep. The study results depict the same that the continuous threat of the virus led to sleep disorder among the masses. Similarly, the impact of the perceived threat of COVID-19 in creating anxiety was found to be significant based on the fact that scholars referred to anxiety developing as a result of feelings of worry, tension (Bandelow et al., 2017), loss of loved ones, work-related stress and uncertain situations (Zwingmann et al., 2008). Simultaneously, the continuous threat of COVID-19 develops a fear of losing loved ones, which can also be seen through accelerated death statics worldwide. Besides, many people lost their jobs during the pandemic due to strict local down and recessive market conditions, further developing a heightened anxiety level among the masses. The same is depicted among the current study respondents.

The impact of the perceived threat of COVID-19 in causing depression amount Hindu residents of Bali have been proved true. These results are according to the findings of LeMoult and Gotlib (2019), who demonstrated the helplessness of the individuals' to deal with the personal losses as a cause of depression. Likewise, during the pandemic, a state of helpless arisen in most of the world among different sectors due to different reasons like students felt depressed due to the closure of educational institutions and lack of physical activities (Özdin \& Bayrak Özdin, 2020), businessman felt depressed due to business losses (Shvetsova et al., 2020), and communities felt depressed due to staying away from their loved ones and threat to lose their loved ones.

In addition to that, the moderating role of Hindu religious coping between the association of perceived threat of COVID-19 and psychological stressors, including perceived stress, insomnia, anxiety, and depression, has been proved by the results. The impact of the Hindu religious coping on psychological stressors depicted that Hinduism believers who practice their religion regularly feel more relaxed and calmer. As many recent scholars have reported, religion is a predictor of wellbeing (Thomas \& Barbato, 2020) and a source of anti-depression (Ahmad et al., 2020; Joyo, 2020). Thus, it has been found that when Hindu religious coping interacts with the perceived threat of COVID-19, it ultimately decreases the intensity of the perceived threat of COVID-19 to cause negative stressors among the societies.

Moreover, those who believe strongly in religious teachings and God are more confident that nothing bad can harm them without their creator's will, who decide everything good for them. This way, they believe that COVID-19 is a kind of test to boost their willpower and harmony to remain determined and focused; God will manage rest. Furthermore, Hindus strongly believe in multiple lives, so they remained focused and imagined the beauty of life after this life. This way, the perceived threat of COVID-19 is mitigated with strong religious beliefs and the practice of daily rituals regularly, resulting in a lower level of psychological stressors.

\section{Theoretical Implications}

The current study offers multiple key theoretical implications for scholars. Firstly, it is established on the grounds of cognitive appraisal theory to determine the impacts of the perceived threat of COVID-19 on various psychological stressors (perceived stress, insomnia, anxiety, and depressions) with different consequences and a unique theoretical framework as well as study setting. This study is exclusive in utilizing cognitive appraisal theory to explain how individuals deal with psychological stress and perceptions of fear and the coping mechanisms to reduce these variables' negative impact. Such theoretical investigations are scarce in religious literature, and 
especially in the crisis of COVID-19. Thus, this research made a significant theoretical advance to the body of knowledge. Secondly, the current study is conducted among the Hindu community individuals living in a Muslim majority country with a multicultural and multi-racial setting where Hindu religious believers are allowed to practice their religious rituals freely without any restrictions. Thus, the whole plot, including theoretical integration, choice of constructs, and study settings, is a major significant advance to the body of knowledge. Moreover, testing a unique framework to bring empirical evidence from the multicultural context of Indonesia brings more novelty strength to the current study.

Thirdly, the moderating role of Hindu religious coping in decreasing the psychological stressors arising due to the perceived threat of COVID-19, specifically focusing on the Hindu religion, has been explored for the first time in literature. Thus, incorporating the Hindu religious coping construct with the perceived threat of COVID-19 and multiple stressors is a major theoretical advance made by this research in the perspective of religious studies in general and Hinduism-related literature in specific. Fourthly, the research on the construct of the perceived threat of COVID-19 is limited in literature, and few studies that explored this construct before are related to its negative effect with positive variables like well-being (Ramkissoon, 2020), varietyseeking (Kim, 2020), etc. In contrast, the current study is unique in exploring its positive effects on various stressors considered negative constructs to hurt community individuals. Thus, making an advance to literature related to COVID-19, stressors and their linkages with religious constructs.

Fifthly, the time lag research attempts in COVID-19 and religious constructs are scarce in the literature. Thus, conducting a time-lagged investigation to determine better causality among COVID-19 related variables and religious variables to impact outcomes is another major theoretical and methodological advance made by the current study. Finally, the interactive effect of the perceived threat of COVID-19 with Hindu religious coping has not been studied before. Hence, the current study attempted to fill this gap by testing the joint effect of positive religious coping and the perceived threat of COVID-19 to decrease the intensity of the effect of the perceived threat of virus in developing negative outcomes, which scholars can further utilize different study settings and with different theoretical frameworks in future.

\section{Practical Implications}

Along with several theoretical implications, the current study offers some valuable practical implications for religious authorities, human resource professionals, practitioners, and policymakers. The current study has been conducted among the Hindu minority community individuals living in a Muslim majority country during the COVID-19. The study results depict that regardless of being the minority, Hindu residents played a positive role in defeating the virus in Bali, Indonesia. The current study further explains that this compact and organized behavior was due to the religious background and teachings, making the believers stay determined and focused during the crisis. Thus, policymakers can utilize this formula of religious practices in normal situations to utilize the positive energies of the society in productive ways for the overall wellbeing of a society and a country. Organizations may also follow similar religious approaches to motivate their employees during crises and stressful work environments. The current study also depicts the consequences of the perceived threat of COVID-19 to develop negative outcomes, which can further lead to extreme situations. Hence, policymakers can develop coping mechanisms other than religion to deal with such stressors among the public to minimize the damage. For this purpose, coaching and counseling centers can be created so that governments have options to deal with acute 
and uncertain circumstances by strengthening the willpower of the masses to promote a positive outlook needed to handle stress and challenges in the post-pandemic era.

Finally, this study is highly significant as it explores the impact of the perceived threat of COVID-19 on the Hindu religious community in terms of perceived stress, anxiety, insomnia, and depression. Previous studies have not explored these variables together, especially in terms of religion and Hindu religious coping. Moreover, this study is unique in pointing to religious coping as a moderator to decrease perceived stress, insomnia, anxiety, and depression in the Hindu community. Hence, making the wellbeing of the religious-based minority community by decreeing various stressors will help maintain harmony, peace, and unity among fellow country members and lead to the nation's wellbeing. Moreover, government officials and policymakers of the other nations should follow the current study's findings to ensure the freedom to practice religion, especially to the minorities, which further gives a sense of satisfaction to the citizens and helps build a healthy nation with strong economic growth.

\section{Limitations and Future Directions}

Along with many strengths, the current study has some limitations, which future researchers can address to devise valuable benefits. First, this study focused on the Hindu community believers living in a Muslim majority country and freely practicing their religious obligations. Future studies can be conducted among believers of different religions to generalize the results based on religious beliefs. Hence a comparative study is recommended in the different religious contexts to validate the findings of this research. Another limitation is that Hinduism believers who regularly visited temples and practiced their beliefs were included in the sample. While Hinduism believers who are not actively practicing may have different results for religious coping intervention. Thus, future studies may help conduct a similar comparative study on Hinduism believers practicing vs. nonpracticing, generalizing this research's findings. Secondly, in this study, Hindu religious coping has been studied as a moderator between the association of perceived threat of COVID-19 and psychological stressors where IV and DV's all were negative constructs. Therefore, Hindu religious coping was found to be moderating the intensity of the association by decreasing the level of various stressors. Whereas, in future studies, the impact of Hindu religious coping can be checked to enhance the level of positive outcomes in an individual, like punctuality, humbleness, activity level and positive attitude, etc. Finally, the current study relies only on quantitative techniques with self-reported measures. In contrast, future studies can be established on qualitative methodology by conducting interactive sessions, focus groups, and interviews exploring the unexplored effects of religious coping among the believers of different religions. A comparative approach among different religions for such a study would surely benefit the field to grow further by adding to the generalizability of this study's findings. Cross-cultural investigations in developing and advanced countries and exploring coping mechanisms of free thinkers and non-believers in the COVID-19 stressing scenario can be another major area of future research. A similar study in organizational employees with organizational outcomes such as creativity and performance, using religious coping may benefit the field to grow in future studies. 


\section{Conclusion}

Keeping in view the disastrous situation created by the COVID-19, this study aims to advance the existing literature and theory by proposing the impact of perceived COVID-19 threat on the various psychological stressors. Thus, grounded on cognitive appraisal theory, the impact of COVID-19 on perceived stress, anxiety, insomnia, depression among the Hindu community residing in Bali, Indonesia, has been assessed. Moreover, the current study examined the contingent effect of Hindu religious coping in mitigating the effect of the pandemic on various stressors. Data were collected using a longitudinal field survey methodology from the Hindu community visiting the Hindu Temples in Bali, Indonesia. Data were analyzed using measurement and structural models in SmartPLS software. Results revealed that pandemic has a drastic effect on creating stress, insomnia, anxiety, and depression. However, that effect was significantly decreased due to the religious beliefs depicted by the Hindu community. Hence proving the "Hindu religious coping" as a significant reliever of various stresses developed during COVID-19. The current study contributed to the body of knowledge regarding religious practices acting as a coping mechanism to help the community cope with crises.

\section{References}

Abu-Raiya, H., Sasson, T., Pargament, K. I., \& Rosmarin, D. H. (2020). Religious coping and health and well-being among jews and muslims in Israel. The International Journal for the Psychology of Religion, 30(3), 202-215.

Ahles, J. J., Mezulis, A. H., \& Hudson, M. R. (2016). Religious coping as a moderator of the relationship between stress and depressive symptoms. Psychology of Religion Spirituality, $8(3), 228$.

Ahmad, A., Rahman, I., \& Agarwal, M. (2020). Factors influencing mental health during COVID19 outbreak: an exploratory survey among indian population. MedRxiv.

Ahmadi, A. (2021). The traces of oppression and trauma to ethnic minorities in Indonesia who experienced rape on the 12 May 1998 tragedy: A review of literature. Journal of Ethnic and Cultural Studies, 8(2), 126-144.

Aliyyah, R. R., Rachmadtullah, R., Samsudin, A., Syaodih, E., Nurtanto, M., \& Tambunan, A. R. S. (2020). The perceptions of primary school teachers of online learning during the COVID19 pandemic period: A case study in Indonesia. Journal of Ethnic and Cultural Studies, 7(2), 90-109.

Aqeel, M., Shuja, K. H., Abbas, J., Rehna, T., \& Ziapour, A. (2020). The Influence of Illness Perception, Anxiety and Depression Disorders on Students Mental Health during COVID19 Outbreak in Pakistan: A Web-Based Cross-Sectional Survey.

Bandelow, B., Michaelis, S., \& Wedekind, D. (2017). Treatment of anxiety disorders. Dialogues in clinical neuroscience, 19(2), 93.

Barzilay, R., Moore, T. M., Greenberg, D. M., DiDomenico, G. E., Brown, L. A., White, L. K., Gur, R. C., \& Gur, R. E. (2020). Resilience, COVID-19-related stress, anxiety and depression during the pandemic in a large population enriched for healthcare providers. Translational psychiatry, 10(1), 1-8.

Bay, P. S., Beckman, D., Trippi, J., Gunderman, R., Terry, C. J. J. o. r., \& health. (2008). The effect of pastoral care services on anxiety, depression, hope, religious coping, and religious problem solving styles: a randomized controlled study. 47(1), 57-69. 
Bosworth, H. B., Park, K. S., McQuoid, D. R., Hays, J. C., \& Steffens, D. C. (2003). The impact of religious practice and religious coping on geriatric depression. International journal of geriatric psychiatry, 18(10), 905-914.

Broekens, J., DeGroot, D., \& Kosters, W. A. (2008). Formal models of appraisal: Theory, specification, and computational model. Cognitive Systems Research, 9(3), 173-197.

Chapman, L. K., \& Steger, M. F. (2010). Race and religion: Differential prediction of anxiety symptoms by religious coping in African American and European American young adults. Depression anxiety, 27(3), 316-322.

Choi, H., \& Choi, H. C. (2019). Investigating tourists' fun-eliciting process toward tourism destination sites: An application of cognitive appraisal theory. Journal of Travel Research, 58(5), $732-744$.

Cohen, S., Kamarck, T., \& Mermelstein, R. (1983). A global measure of perceived stress. Journal of health and social behavior, 385-396.

Conway III, L. G., Woodard, S. R., \& Zubrod, A. (2020a). Social psychological measurements of COVID-19: Coronavirus perceived threat, government response, impacts, and experiences questionnaires [Working Paper].

Conway III, L. G., Woodard, S. R., \& Zubrod, A. (2020b). Social psychological measurements of COVID-19: Coronavirus perceived threat, government response, impacts, and experiences questionnaires. University of Montana.

Counted, V., Pargament, K. I., Bechara, A. O., Joynt, S., \& Cowden, R. G. (2020). Hope and wellbeing in vulnerable contexts during the COVID-19 pandemic: does religious coping matter? The Journal of Positive Psychology, 1-12.

Dalle, J., \& Ariffin, A.M. (2018). The impact of technologies in teaching interaction design. Journal of Advanced Research in Dynamical and Control Systems. 10(4-Special Issue), 1779-1783.

Feng, Y., Zong, M., Yang, Z., Gu, W., Dong, D., \& Qiao, Z. (2020). When altruists cannot help: the influence of altruism on the mental health of university students during the COVID-19 pandemic. Globalization and Health, 16(1), 1-8.

Fetzer, T., Hensel, L., Hermle, J., \& Roth, C. (2020). Coronavirus perceptions and economic anxiety. Review of Economics Statistics, 1-36.

Foroutani, Y. (2020). Ethnic or Religious Identities?: Multicultural Analysis in Australia from Socio-Demographic Perspective. Journal of Ethnic and Cultural Studies, 7(1), 1-19.

Francis, B., Gill, J. S., Yit Han, N., Petrus, C. F., Azhar, F. L., Ahmad Sabki, Z., Said, M. A., Ong Hui, K., Chong Guan, N., \& Sulaiman, A. H. (2019). Religious coping, religiosity, depression and anxiety among medical students in a multi-religious setting. International journal of environmental research public health, 16(2), 259.

Garbe, L., Rau, R., \& Toppe, T. (2020). Influence of perceived threat of Covid-19 and HEXACO personality traits on toilet paper stockpiling. Plos one, 15(6), e0234232.

Greene, M. V., \& Park, G. (2021). Promoting Reflexivity During the COVID-19 Pandemic. American Journal of Qualitative Research, 5(1), 23-29. https://doi.org/10.29333/ajqr/9717

Hair, J. F., Black, W. C., Babin, B. J., \& Anderson, R. E. (2010). Multivariate Data Analysis - A Global Perspective (7 ed.). Pearson Prentice Hall.

Henseler, J., Ringle, C. M., \& Sinkovics, R. R. (2009a). The use of partial least squares path modeling in international marketing. In R. R. Sinkovics \& P. N. Ghauri (Eds.), New Challenges to International Marketing (Advances in International Marketing, Volume 20 (Vol. 20, pp. 277-319). Emerald Group Publishing Limited. https://doi.org/https://doi.org/10.1108/S1474-7979(2009)0000020014 
Henseler, J., Ringle, C. M., \& Sinkovics, R. R. (2009b). The use of partial least squares path modeling in international marketing. In New challenges to international marketing (pp. 277-319). Emerald Group Publishing Limited. https://doi.org/https://doi.org/10.1108/S1474-7979(2009)0000020014

Heo, G. J. (2014). Religious coping, positive aspects of caregiving, and social support among Alzheimer's disease caregivers. Clinical Gerontologist, 37(4), 368-385.

Hertenstein, E., Feige, B., Gmeiner, T., Kienzler, C., Spiegelhalder, K., Johann, A., JanssonFröjmark, M., Palagini, L., Rücker, G., \& Riemann, D. (2019). Insomnia as a predictor of mental disorders: a systematic review and meta-analysis. Sleep medicine reviews, 43, 96105.

Irshad, M., Khattak, S. A., Hassan, M. M., Majeed, M., \& Bashir, S. (2020). How perceived threat of Covid-19 causes turnover intention among Pakistani nurses: A moderation and mediation analysis. International journal of mental health nursing.

Jiang, Y., \& Dewaele, J.-M. (2020). The predictive power of sociobiographical and language variables on foreign language anxiety of Chinese university students. System, 89, 102207. https://doi.org/https://doi.org/10.1016/j.system.2020.102207

Joyo, P. R. (2020). Loka Samgraha: Hindu Philosophical Foundation of Social Behaviors in Indonesia New Normal Era. Jayapangus Press Books, 421-445.

Kalyani, G. S. (2020). Psychosocial Changes and Coping Strategies in Home Quarantined University Students of Pakistan During COVID-19 Pandemic. Esculapio, 16(1).

Kasim, U., Hasibuan, F. Y., Reksowibowo, B., \& Suganda, A. (2020). Reformulation of Work Relationships on the Outsourcing System in Indonesian Order to Protecting the Rights of Workers. JL Pol'y \& Globalization, 103, 66.

Katipana, M. V., Wiryana, M., Aryasa, E. T., \& Pradhana, A. P. (2021). Perioperative management in obstetric patients with suspected COVID-19 at Bali, Indonesia: Case series. Bali Journal of Anesthesiology, 5(1), 40.

Kim, J. (2020). Impact of the perceived threat of COVID-19 on variety-seeking. Australasian Marketing Journal, 28(3), 108-116.

Kroenke, K., Spitzer, R. L., \& Williams, J. B. (2001). The PHQ-9: validity of a brief depression severity measure. Journal of general internal medicine, 16(9), 606-613.

Lee, E.-H. (2012). Review of the psychometric evidence of the perceived stress scale. Asian nursing research, 6(4), 121-127.

LeMoult, J., \& Gotlib, I. H. (2019). Depression: A cognitive perspective. Clinical Psychology Review, 69, 51-66.

Limcaoco, R. S. G., Mateos, E. M., Fernandez, J. M., \& Roncero, C. (2020). Anxiety, worry and perceived stress in the world due to the COVID-19 pandemic, March 2020. Preliminary results

Liu, S., Lithopoulos, A., Zhang, C.-Q., Garcia-Barrera, M. A., \& Rhodes, R. E. (2021a). Personality and perceived stress during COVID-19 pandemic: Testing the mediating role of perceived threat and efficacy. Personality individual differences, 168.

Liu, S., Lithopoulos, A., Zhang, C.-Q., Garcia-Barrera, M. A., \& Rhodes, R. E. J. (2021b). Personality and perceived stress during COVID-19 pandemic: Testing the mediating role of perceived threat and efficacy. Personality individual differences, $168(1)$.

Luczak, C., \& Kalbag, A. (2018). The appropriateness and effectiveness of cross-aged peer mentoring in the learning environment. International Journal of Humanities, Arts and Social Sciences, 4(2), 76-84. https://doi.org/https://dx.doi.org/10.20469/ijhss.4.10003-2 
Mansoor, M. (2021). An interaction effect of perceived government response on COVID-19 and government agency's use of ICT in building trust among citizens of Pakistan. Transforming Government: People, Process and Policy, Vol. ahead-of-print(No. ahead-of-print). https://doi.org/https://doi.org/10.1108/TG-01-2021-0002

Mansoor, M., Awan, T. M., \& Syed, F. (2020). Positive emotions as underlying mechanism between customer gratitude and behavioural intentions. JABS, 6(1), 09-20. https://doi.org/https://doi.org/10.20474/jabs-6.1.2

Mansoor, M., \& Noor, U. (2019). Determinants of Green Purchase Intentions: Positive Word of Mouth as moderator. Journal of Business \& Economics, 11(2), 143-160.

McElroy-Heltzel, S. E., Van Tongeren, D. R., Gazaway, S., Ordaz, A., Davis, D. E., Hook, J. N., Davis, E. B., Aten, J. D., Shannonhouse, L. R., \& Stargell, N. A. (2018). The role of spiritual fortitude and positive religious coping in meaning in life and spiritual well-being following Hurricane Matthew. Journal of Psychology Christianity, 37(1), 17-27.

Megatsari, H., Laksono, A. D., Ibad, M., Herwanto, Y. T., Sarweni, K. P., Geno, R. A. P., \& Nugraheni, E. (2020). The community psychosocial burden during the COVID-19 pandemic in Indonesia. Heliyon, 6(10), e05136.

Moghanibashi-Mansourieh, A. (2020). Assessing the anxiety level of Iranian general population during COVID-19 outbreak. Asian journal of psychiatry, 51, 102076.

Mohammadzadeh, A., \& Najafi, M. (2020). The comparison of death anxiety, obsession, and depression between Muslim population with positive and negative religious coping. Journal of religion health, 59(2), 1055-1064.

Morin, C. M., Belleville, G., Bélanger, L., \& Ivers, H. (2011). The Insomnia Severity Index: psychometric indicators to detect insomnia cases and evaluate treatment response. Sleep, 34(5), 601-608.

Namli, U. (2021). Behavioral Changes among Street Level Drug Trafficking Organizations and the Fluctuation in Drug Prices Before and During the Covid-19 Pandemic. American Journal of Qualitative Research, 5(1), 1-22. https://doi.org/10.29333/ajqr/9691

Nedal, O. A., \& Alcoriza, M. G. O. (2018). Challenges in education: The untold story of students in Lanao Kapanglao, Glan, Sarangani province. Journal of Advances in Humanities and Social Sciences, 4(3), 118-126. https://doi.org/https://doi.org/10.20474/jahss-4.3.1

Ng, G. C., Mohamed, S., Sulaiman, A. H., \& Zainal, N. Z. (2017). Anxiety and depression in cancer patients: the association with religiosity and religious coping. Journal of religion health, 56(2), 575-590.

Noor, U., Mansoor, M., \& Rabbani, S. (2021). Brand hate and retaliation in Muslim consumers: does offensive advertising matter? Journal of Islamic Marketing, Vol. ahead-of-print(No. ahead-of-print). https://doi.org/https://doi.org/10.1108/JIMA-10-2020-0316

O'Brien, B., Shrestha, S., Stanley, M. A., Pargament, K. I., Cummings, J., Kunik, M. E., Fletcher, T. L., Cortes, J., Ramsey, D., \& Amspoker, A. B. (2019). Positive and negative religious coping as predictors of distress among minority older adults. International journal of geriatric psychiatry, 34(1), 54-59.

Özdin, S., \& Bayrak Özdin, Ş. (2020). Levels and predictors of anxiety, depression and health anxiety during COVID-19 pandemic in Turkish society: The importance of gender. International Journal of Social Psychiatry, 66(5), 504-511.

Paredes, M. R., Apaolaza, V., Fernandez-Robin, C., Hartmann, P., \& Yañez-Martinez, D. (2021a). The impact of the COVID-19 pandemic on subjective mental well-being: The interplay of perceived threat, future anxiety and resilience. Personality and Individual Differences, 170, 110455. https://doi.org/https://doi.org/10.1016/j.paid.2020.110455 
Paredes, M. R., Apaolaza, V., Fernandez-Robin, C., Hartmann, P., \& Yañez-Martinez, D. (2021b). The impact of the COVID-19 pandemic on subjective mental well-being: The interplay of perceived threat, future anxiety and resilience. Personality Individual Differences, 170, 110455.

Park, C. L., Holt, C. L., Le, D., Christie, J., \& Williams, B. R. (2018). Positive and negative religious coping styles as prospective predictors of well-being in African Americans. Psychology of religion spirituality, 10(4), 318.

Patel, D., Steinberg, J., \& Patel, P. (2018). Insomnia in the elderly: a review. Journal of Clinical Sleep Medicine, 14(6), 1017-1024.

Pillai, V., Roth, T., Mullins, H. M., \& Drake, C. L. (2014). Moderators and mediators of the relationship between stress and insomnia: stressor chronicity, cognitive intrusion, and coping. Sleep, 37(7), 1199-1208A.

Putnam, K. T., Wilcox, M., Robertson-Blackmore, E., Sharkey, K., Bergink, V., Munk-Olsen, T., Deligiannidis, K. M., Payne, J., Altemus, M., \& Newport, J. (2017). Clinical phenotypes of perinatal depression and time of symptom onset: analysis of data from an international consortium. The Lancet Psychiatry, 4(6), 477-485.

Putra, A. K., Najwan, J., Rahmalia, R., \& Daud, S. M. (2021). A Normative Juridical Study of Internationalization of Indonesian Higher Education Institution. In Higher Education Challenges in South-East Asia (pp. 74-97). IGI Global.

Radcliffe, C., \& Lester, H. (2003). Perceived stress during undergraduate medical training: a qualitative study. Medical education, 37(1), 32-38.

Rahiem, M., \& Rahim, H. (2020). The Sultan and the Soup: A Javanese Cultural Response to COVID-19. Journal of Ethnic and Cultural Studies, 8(1), 43-65.

Ramkissoon, H. (2020). COVID-19 Place confinement, pro-social, pro-environmental behaviors, and residents' wellbeing: A new conceptual framework. Frontiers in Psychology, 11, 2248. https://doi.org/https://doi.org/10.3389/fpsyg.2020.02248

Rodriguez, L. M., Litt, D. M., \& Stewart, S. H. (2020). Drinking to cope with the pandemic: The unique associations of COVID-19-related perceived threat and psychological distress to drinking behaviors in American men and women. Addictive behaviors, 110, 106532.

Sawatsuk, B., Darmawijaya, I. G., Ratchusanti, S., \& Phaokrueng, A. (2018). Factors determining the sustainable success of community-based tourism: Evidence of good corporate governance of Mae Kam Pong Homestay, Thailand. International Journal of Business and Economic Affairs, 3(1), 13-20. https://doi.org/ https://doi.org/10.24088/IJBEA-2018-31002

Shah, M., Hasan, S., Malik, S., \& Sreeramareddy, C. T. (2010). Perceived stress, sources and severity of stress among medical undergraduates in a Pakistani medical school. BMC medical education, 10(1), 1-8.

Shvetsova, O., Zhirnov, A., Adeel, A. B., Catalano, M., Catalano, O., Chu, H., Dumond, G. K., Ghincea, G.-M., Means, J., \& Muftuoglu, E. (2020). Constitutional and Institutional Structural Determinants of Policy Responsiveness to Protect Citizens from Existential Threats: Covid-19 and Beyond. International Journal of Business and Economic Affairs (IJBEA), 3(1), 13-20. https://doi.org/ https://doi.org/10.24088/IJBEA-2018-31002

Sikhangezile, N., \& Modise, M. A. (2020). Social distancing, cultural and psychological effects on learners in a rural setting in Zimbabwe. Journal of Ethnic and Cultural Studies, 7(3), 200209.

Singaram, V. S., \& Saradaprabhananda, S. (2020). Cultural thanatology: an exploration of the religious, spiritual, and existential concerns of elderly terminally-ill diasporic Hindus. Journal of Religion, Spirituality Aging, 1-21. 
So, J., Kuang, K., \& Cho, H. (2016). Reexamining fear appeal models from cognitive appraisal theory and functional emotion theory perspectives. Communication Monographs, 83(1), 120-144.

Spitzer, R. L., Kroenke, K., Williams, J. B., \& Löwe, B. (2006). A brief measure for assessing generalized anxiety disorder: the GAD-7. Archives of internal medicine, 166(10), 10921097.

Sulistyawati, S., Rokhmayanti, R., Aji, B., Wijayanti, S. P. M., Hastuti, S. K. W., Sukesi, T. W., \& Mulasari, S. A. (2021). Knowledge, Attitudes, Practices and Information Needs During the COVID-19 Pandemic in Indonesia. Risk Management and Healthcare Policy, 14, 163.

Szabo, A., English, A. S., Zhijia, Z., Jose, P., Ward, C., \& Jianhong, M. (2017). Is the utility of secondary coping a function of ethnicity or the context of reception? A longitudinal study across Western and Eastern cultures. Journal of Cross-Cultural Psychology, 48(8), 12301246.

Tarakeshwar, N., Pargament, K. I., \& Mahoney, A. (2003). Initial development of a measure of religious coping among Hindus. Journal of community psychology, 31(6), 607-628.

Thomas, J., \& Barbato, M. (2020). Positive religious coping and mental health among Christians and Muslims in response to the COVID-19 pandemic. Religions, 11(10), 498.

Tsurumi, T., Yamaguchi, R., Kagohashi, K., \& Managi, S. (2020). Are cognitive, affective, and eudaimonic dimensions of subjective well-being differently related to consumption? Evidence from Japan. Journal of Happiness Studies, 1-24.

Tyler, T. R., \& Cook, F. L. (1984). The mass media and judgments of risk: Distinguishing impact on personal and societal level judgments. Journal of Personality and Social Psychology, 47(4), 693.

Van Tongeren, D. R., Worthington Jr, E. L., Davis, D. E., Hook, J. N., Reid, C. A., \& Garthe, R. C. (2018). Positive religious coping in relationships predicts spiritual growth through communication with the sacred. Psychology of Religion Spirituality, 10(1), 55.

Voitsidis, P., Gliatas, I., Bairachtari, V., Papadopoulou, K., Papageorgiou, G., Parlapani, E., Syngelakis, M., Holeva, V., \& Diakogiannis, I. (2020). Insomnia during the COVID-19 pandemic in a Greek population. Psychiatry research, 289, 113076.

Wasike, C. N. (2017). Financial regulation as moderating, in luence of corporate governance, institutional quality, human capital and irm size on inancial institutions performance in Kenya. Journal of Administrative and Business Studies, 3(6), 292-304.

Wu, B., \& Ida, A. K. (2018). Ethnic diversity, religion, and opinions toward legalizing abortion: The case of Asian Americans. Journal of Ethnic and Cultural Studies, 5(1), 94-109.

Yamamori, K. (2019). Classroom practices of low-cost STEM education using scratch. Journal of Advanced Research in Social Sciences and Humanities Volume, 4(6), 192-198. https://doi.org/https://dx.doi.org/10.26500/JARSSH-04-2019-0601

Zwingmann, C., Müller, C., Körber, J., \& Murken, S. (2008). Religious commitment, religious coping and anxiety: a study in German patients with breast cancer. European Journal of Cancer Care, 17(4), 361-370. 


\section{Notes on Contributions}

I Nyoman Sueca is a lecturer of Hindu religious education at Universitas Hindu Negeri I Gusti Bagus Sugriwa Denpasar, Bali, Indonesia. E-mail: inyomanseuca64@gmail.com and ORCID ID: 0000-0001-6561-0254. He graduated his Bachelor's study of Religious Education at Sekolah Tinggi Agama Hindu Parama Dharma Denpasar (1998); Master of Education Management at University of Surabaya (2005); Doctoral Studies in Hindu Religious Education at University of Hindu Indonesia (2015); and has followed post-doctoral at KITLV affiliated with Leiden University, Netherlands (2013). Two of the four research books that he has compiled are "Traditional Pedagogi: Lokalitas Sebagai Budaya Tanding" and "Religious Habitus".

I Wayan Sumertha is a lecturer in Hindu Theology at the Postgraduate Program (S2) at the Gde Pudja State Hindu Institute of Mataram, West Nusa Tenggara. He is also seconded as a Lecturer in the Undergraduate Program (S1) at the Dharmaduta faculty, Hindu Religion Philosophy Study Program, Brahmawidya (Theology) Department at the Gde Pudja State Hindu Institute of Mataram, West Nusa Tenggara. E-mail: iwayansumertha63@gmail.com and ORCID ID: 00000001-5931-5259. I Wayan Sumertha Completed his Bachelor of Religion and Culture at the Faculty of Religion and Culture at the Hindu University of Indonesia (1986); Bachelor's Education (S1), majoring in Hindu Religion at the Hindu University of Indonesia (1989); Master of Religion at I Gusti Bagus Sugriwa State Hindu University, Denpasar Bali (2006); Doctoral Studies in Religious Sciences at I Gusti Bagus Sugriwa State Hindu University, Denpasar, Bali (2016); and several research results that have been carried out, one of which is about "Pura Lingsar, a historical study of theology" (2014), competitive research on competitive grants from the Directorate General of Hindu Guidance, Ministry of Religion, Jakarta.

I Wayan Winaja is a Professor in the field of religious and cultural sciences at the Postgraduate Program at the Universitas Hindu Indonesia (UNHI) Denpasar. E-mail: winaja@ unhi.ac.id and ORCID ID: 0000-0002-0197-4507, born in Tabanan, May 30, 1962. After graduating from SDN 3 Kerambitan in 1974, continued his secondary education at SMPN Kerambitan graduated in 1978, and graduated from Denpasar State Senior High School/Junior High School majoring in Science in 1981. Completed his undergraduate education in the Department of Chemistry Education, Universitas Udayana in 1986 and his master's education in Masters in Cultural Studies at Universitas Udayana in 2000. Earned a Doctorate degree in S3 Cultural Studies, Postgraduate Program at Universitas Udayana in 2012. 